\title{
Assessment of Biochemical and Molecular Biomarkers for Diagnosis $\backslash$ Prognosis of Chronic Lymphocytic Leukemia in Iraqi Patients
}

\author{
AL- Dahery H.S. ${ }^{1}$, Dr. Alwan A.F. ${ }^{2}$, Dr. Shabeeb Z.A. ${ }^{3}$ \\ ${ }^{1}$ Department Medical biotechnology, College of Applied Biotechnology, AL-Nahrain University - IRAQ \\ ${ }^{2}$ Professor, FICMS (int.med), FICMS (clin.hem), National Center of Hematology \\ ${ }^{3}$ Assistant Professor, Clinical Immunology, National Center of Hematology
}

\begin{abstract}
Assessment of biochemical and molecular biomarkers for diagnosis patients. Background: Glutathione (GSH) is an important non-enzymatic antioxidant preventing damage to important cellular components caused by reactive oxygen species such as free radicals and peroxides (Humphries, et al., 2013). GSH protect cells against toxic free radicals involved in the synthesis and repair of DNA, and serves as a reductant antioxidant in oxidation reduction resulting in the formation of oxidized GSH (Wu et al, 2004). Malondialdehyde (MDA) is made up by free radicals during tissue damage when (ROS) degrade polyunsaturated lipids, and used in the measurement of oxidative stress (Halliwell, 2007). ROS-related damages in lymphocytes from patients with monoclonal B-lymphocytosis and CLL reported increased levels of oxidatively modified DNA and lipids in the sera of untreated CLL patients due to increased oxidative phosphorylation in CLL cells (Jitschin, et. al., 2014). Objectives: To assess the hematological profile in CLL patients and healthy subjects. Moreover, to detect the antioxidant defense mechanisms in serum of CLL patients and healthy subjects such as glutathione (GSH), and malondialdehyde (MDA). Finally, to determine the IGHV mutational status using Rt-PCR and DNA sequencing. Methodology: This study was conducted on randomly selected 55 CLL patients referred to the National Center of hematology $\backslash$ AL-Mustansiyria University. CLL patients included (18) newly diagnosed untreated patients (12 males and 6 females), with a mean age of (55 \pm 12$)$ yr and age range of (40-80)yr. This study includes (37) already diagnosed CLL patients who are currently receiving treatment. They included (28) males and (9) females, with a mean age of (57 \pm 9$)$ yr and on age range of (45-71) yr. Nineteen (19) apparently healthy subjects were also involved in this study. They included (9) males and (10) females, with a mean age of $(61 \pm 17)$ yr. and an age range of (30-90) yr. Results: Serum levels of the major antioxidant, glutathione (GSH) showed a significant decline and serum levels of malondialdehyde (MDA) were significantly elevated in untreated CLL patients. Real Time-PCR results showed the presence of mutated in IgVH in 3/8 untreated and 4/8 treated CLL patients, while healthy controls did not show any mutation in IgVH. Conclusion: CLL patients of the present study showed various biochemical, and molecular changes.
\end{abstract}

Keywords: Chronic Lymphocytic Leukemia, Glutathione (GSH), Malondialdehyde (MDA), IgVH

\section{Introduction}

Chronic lymphocytic leukemia (CLL) is the most common type of leukemia in the Western world accounting for $40 \%$ of all leukemia characterized by the clonal proliferation and accumulation of B-lymphocytes. It affects mainly elderly patients as the median age of diagnosis is about 72 years and the male to female ratio is $2: 1$. The symptoms of the disease arise from a clonal excess of B- cells caused mainly by defects that prevent programmed cell death (apoptosis). In symptomatic patients the presence of unmutated Ig heavy chain variable region, the presence of ZAP-70, and CD-38 expression predict worse clinical outcome (Kyrtsonis, et al., 2013). This genetic diversity of cancer cells is essential for progression of the disease (Calin, et al., 2005). On the other hand, accumulation of reactive oxygen species (ROS) from antioxidant deficiency, mitochondrial dysfunction, inflammation, phagocytosis (myeloperoxidase activity), exogenous stress (exogenous oxidants, redox cycling agents, UV irradiation, chemicals, endotoxins, and hyperoxia) result in a state of redox imbalance known as oxidative stress. ROS alter biological macromolecules (DNA, carbohydrates, proteins, and lipids). which contributes to genomic instability. Previous analyses have demonstrated an impairment in the antioxidant defense system and an enhancement in the damaged DNA base 8-oxo-2- deoxyguanosine (8-oxo-dG) in both the preleukemic state of monoclonal B-cell lymphocytosis and CLL (Oltra, et al., 2001; Collado, et al., 2012).

In normal B-cells, any immune complex or antigen induced germinal center GC enlargement formation of new ones as small B-cells surrounding GC, appearance of memory B-cells and development of $\mathrm{Ig}$ production cells of high affinity. During this particularly frenetic bout of cell division, somatic hypermutation of B-cell Ig genes occurs encoded by unmutated germ-line genes represent a form of evolutionary memory so-called 'natural antibody'. Randomly, some mutated daughter cells will have higher affinity for antigen, some the same or lower and others perhaps none at all. Similarly, mutations in the framework regions may be 'silent' or, if they disrupt the folding of the protein, give rise to nonfunctional molecules (Küppers, 2004; Dooley, et al., 2006). Clones use either mutated or unmutated IGHV genes (Damle, et al., 1999), with distinct clinical courses, the IGHV repertoire in CLL is not random and differs between U-CLL and M-CLL as well as between CLL cells and normal B cells (kipps, et al., 2000). 


\section{International Journal of Science and Research (IJSR) \\ ISSN (Online): 2319-7064}

Index Copernicus Value (2013): 6.14 | Impact Factor (2015): 6.391

\section{Subjects, Materials and Methods}

This study was conducted on 55 adult Iraqi patients referred to the National Center of hematology, AL-Mustansiyria university for evaluation and treatment during the period extending from Oct. 2013 to Sept. 2015. They were diagnosed as having CLL based on physical examination by a specialist, morphological assessment of peripheral blood films and bone marrow smear by aspirate (BSA) examination ( in difficult cases), as well as flow cytometric immunophenotypic profile.

CLL patients included (18) newly diagnosed, untreated patients (12 males and 6 females), with a mean age of $(55 \pm 12)$ yr. and an age range of(40-80)yr. Nineteen (19) patients, apparently healthy subjects were also involved in this study. They included (9) males and (10) females, with a mean age of $(61 \pm 17) \mathrm{yr}$. and an age range of (30-90) yr.

A male patient at the age of $25 \mathrm{yrs}$ was excluded from the study because of his young age. This patient died five days after admission to the hospital. It is not unusual to diagnoses CLL in younger individuals at an age range from 30 to 39 years (Hernández, et.al., 1995).
Another male patient was excluded from the study. He was the only patient with stage A among all patients of the present study.

The treatment given to CLL patients consist of the following combination therapy Rituximab, Fludarabine and Cyclophosphamide ( RFC), Rituximab was given at 375 $\mathrm{mg} / \mathrm{m}^{2}$ on day one (or over 2 days), Fludarabine given at 30 $\mathrm{mg} / \mathrm{m}^{2}$ on day one to day three, , and Cyclophosphamide at $300 \mathrm{mg} / \mathrm{m}^{2}$ on day one to day five (Hallek et al., 2008; Catovsky, et al., 2011; Pettitt et al., 2012).

\section{Research Protocol}

Collectively, the present research protocol encompass two groups of CLL patients. First, (18) newly diagnosed patients with pre-treatment values, and followed up for a median of 4.5 months RFC therapy. Second, (37) already treated CLL patients with a median of 21.5 months of therapy; as illustrated in figure 1

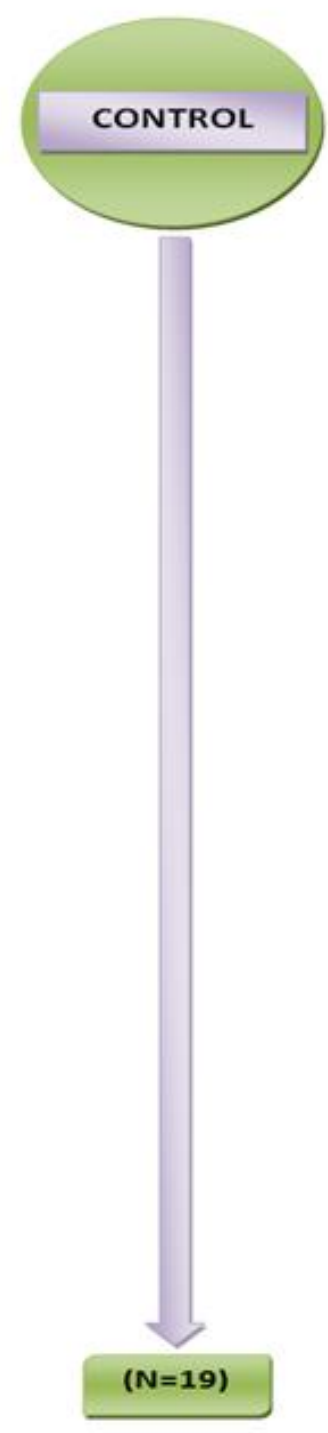

CLL patients

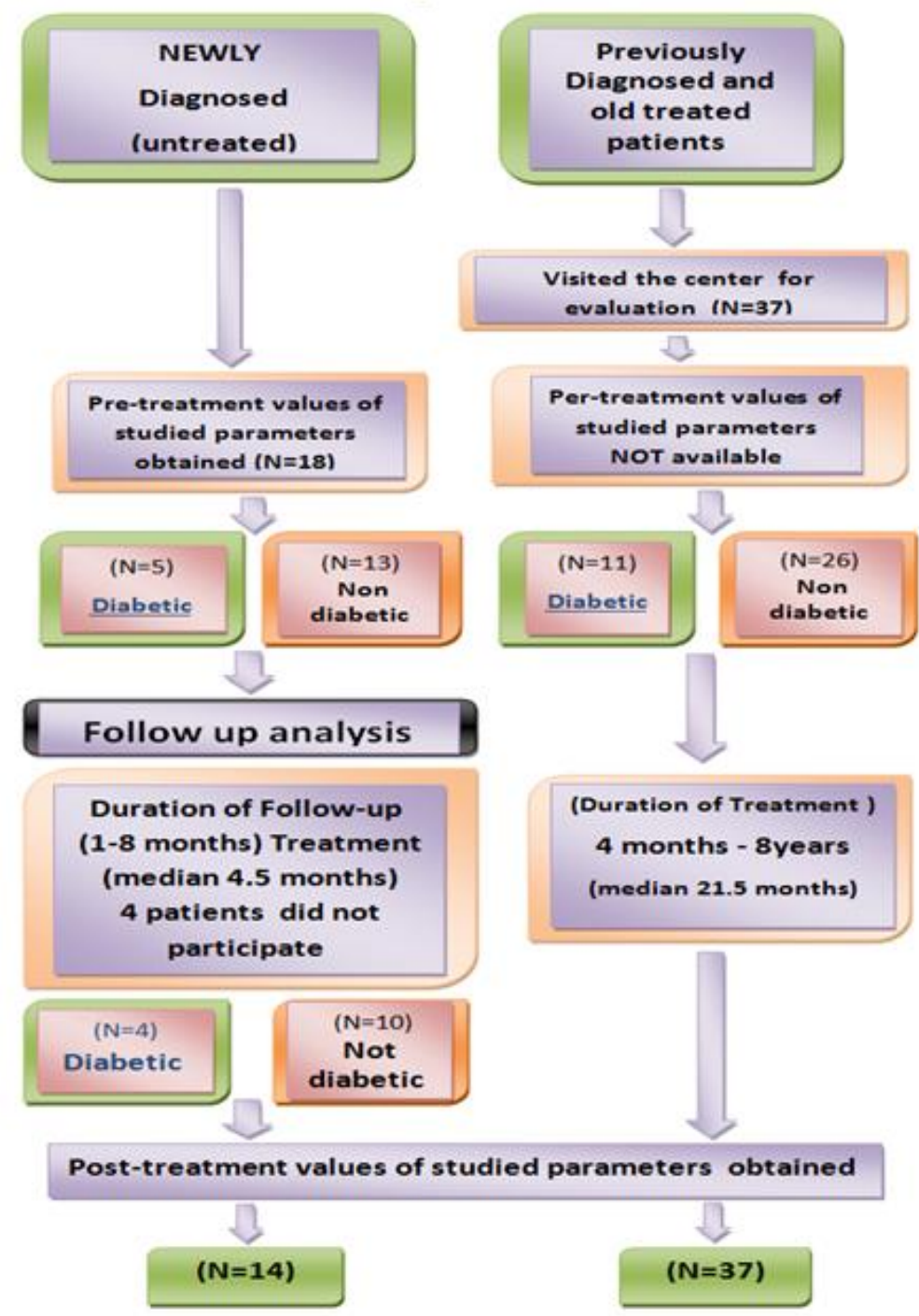

Figure 1: Studied Parameters in the present protocol

Volume 5 Issue 6, June 2016 www.ijsr.net

Licensed Under Creative Commons Attribution CC BY 


\section{International Journal of Science and Research (IJSR) \\ ISSN (Online): 2319-7064 \\ Index Copernicus Value (2013): 6.14 | Impact Factor (2015): 6.391}

Studied Parameters in the present protocol:

1) Biochemical Profile: Antioxidant status; Glutathione (GSH) /Malondialdehyde (MDA).

2) Molecular Profile: (IGHV mutational status and DNA sequencing).

\section{Antioxidant enzymes}

\section{Glutathione (GSH)}

GSH Assay Procedure (Cusabio, U.S.A.)

All reagents and samples were brought to room temperature before use. The sample was centrifuged again after thawing before the assay. All samples and standards were assayed in duplicate.

All reagents, working standards, and samples were prepared as directed in the previous sections. The number of wells to be used was determined according to the Assay Layout Sheet and put any remaining wells and the desiccant were put back into the pouch, ziplocwas sealed, stored unused wells at $4^{\circ} \mathrm{C}$. $100 \mu \mathrm{l}$ of standard and serum per well were added, covered with the adhesive strip provided, and incubated for 2 hours at $37^{\circ} \mathrm{C}$. A plate lay out is provided to record standards and samples assayed.The liquid of each

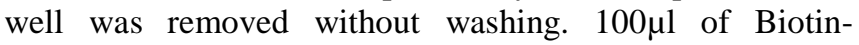
antibody (1x) was added to each well. covered with a new adhesive strip. Then incubated for 1 hour at $37^{\circ} \mathrm{C}$. Each well was aspirated and washed, repeating the process two times for a total of three washes. Washing was done by filling

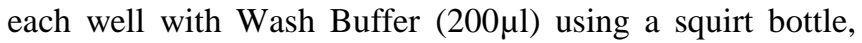
multi-channel pipette, manifold dispenser, or autowasher, and let it stand for 2 minutes, complete removal of liquid at each step is essential to good performance. After the last wash, any remaining wash Buffer was removed by aspirating ordecanting. The plate was inverted and blotted it against clean paper towels.100 $\mu 1$ of HRP-avidin (1x) was added to each well. The microtiter plate was covered with a new adhesive strip and incubated for 1 hour at $37^{\circ} \mathrm{C}$. The aspiration/wash was processed for five times as in step 6 . $90 \mu 1$ of TMB Substrate was added to each well, incubated for $15-30$ minutes at $37^{\circ} \mathrm{C}$, and protected from light. $50 \mu \mathrm{l}$ of Stop Solution was added to each well, and the plate was gently tapped to ensure a thorough mixing. The optical density of each well was determined within 5 minutes, using a microplate reader set to $450 \mathrm{~nm}$. If a wavelength correction is available, set to $540 \mathrm{~nm}$ or $570 \mathrm{~nm}$. The readings at 540 $\mathrm{nm}$ or $570 \mathrm{~nm}$ were subtracted from the readings at $450 \mathrm{~nm}$. This subtraction will correct the optical imperfections in the plate.

\section{Malondialdehyde (MDA)}

\section{MDA Assay Procedure (Cusabio, U.S.A.):}

All reagents were brought and samples to room temperature before use. All samples, standards, and controls were assayed in duplicate. 100 $\mu$ l of Standard, Blank, or serum Sample were added per well, covered with the adhesive strip and incubated for 2 hours at $37^{\circ} \mathrm{C}$. The liquid was removed from each well without washing. $100 \mu$ l of Biotin-antibody working solution was added to each well and incubated for 1 hour at $37^{\circ} \mathrm{C}$. Each well was aspirated and washed three times for a total of three washes. The wash was done by filling each well with Wash Buffer $(200 \mu 1)$ using a squirt bottle. Complete removal of liquid at each step is essential to good performance. After the last wash, any remaining Wash Buffer was removed by aspirating or decanting. The plate was inverted and blotted it against clean paper towels. $100 \mu \mathrm{l}$ of HRP-avidin working solution was added to each well. The microtiter plate was covered with a new adhesive strip, and incubated for 1 hour at $37^{\circ} \mathrm{C}$. The aspiration and washing was repeated three times. $90 \mu \mathrm{l}$ of TMB Substrate was added to each well and incubated for 30 minutes at $37^{\circ} \mathrm{C}$. $50 \mu$ of Stop Solution was added to each well. The optical density of each well was determined within 30 minutes, using a microplate reader set to $450 \mathrm{~nm}$.

\section{Molecular study}

\section{Separation of monocular cells ( Meltinyl Biotech)}

The mononuclear cells (MNCs) were separated from blood sample by density gradient centrifugation according to the protocol described by Moreton, et al. (2005). Fresh EDTA blood was diluted 1:1 in normal saline; mixed gently until it was homogenous. The cell suspension was centrifuged in cooling centrifuge (at $4^{\circ} \mathrm{C}, 2000 \mathrm{rpm}$ for $10 \mathrm{~min}$ ) on equal volume of Ficoll-Paque. The upper layer was drawn off using a clean Pasteur pipette, the MNCs rich zone called (Buffy coat) was isolated, transferred into a new $10 \mathrm{ml}$ tube and washed twice with normal saline through centrifugation at $2000 \mathrm{rpm}$ for $8 \mathrm{~min}$ and $1000 \mathrm{rpm}$ for $10 \mathrm{~min}$, respectively. The final pellet was re-suspended with normal saline and was considered ready for isolation of DNA and determination of IGHV mutational status using RT-PCR and DNA sequencing.

One hundred $\mu$ l of lymphocytes were added to the RNA Lysis Buffer. $175 \mu$ l of RNA Lysis Buffer were added to the cells. The cells were suspended and by pipetting. $350 \mu$ of RNA Dilution Buffer was added and mixed by inverting 3-4 times.The tubes were placed in a water bath at $70^{\circ} \mathrm{C}$ for 3 minutes. Then centrifuged at $14000 \mathrm{rpm}$ for $10 \mathrm{~min}$. The cleared lysate was transferred to a sterile tube by pipetting. $200 \mu 1$ of $95 \%$ ethanol was added to the cleared lysate, and mixed by pipetting 3-4 times. The mixture was transferred to the Spin Column Assembly. Centrifuged at 12,000-14,000 $\times$ $\mathrm{g}$ for one minute. Spin Basket was taken from the Spin Column Assembly, and discarded the liquid was discarded in the Collection Tube. The Spin Basket was then back into the Collection Tube. $600 \mu \mathrm{l}$ of RNA Wash Solution was added to the Spin Column Assembly, centrifuged at 12,000-14,000 $\times \mathrm{g}$ for 1 minute. The collection Tube was emptied as before and placed it in a rack. For each isolation to be performed, DNase incubation was prepared by mix combining $40 \mu$ l Yellow Core Buffer, $5 \mu 10.09 \mathrm{M} \mathrm{MnCl} 2$ and $5 \mu$ l of DNase I enzyme per sample in a sterile tube (in this order). Only the amount of DNase incubation mix required was prepared and pipetted carefully, and mixed by gentle pipetting; without vortex. The DNase I on ice was kept while it is thawed. $50 \mu$ l of this freshly prepared DNase incubation mix was applied directly to the membrane inside the Spin Basket, and incubated for 15 minutes at $20-25^{\circ} \mathrm{C}$. After incubation, $200 \mu \mathrm{l}$ of DNase Stop Solution was added to the Spin Basket, and centrifuged at $12,000-14,000 \times \mathrm{g}$ for 1 minute. $600 \mu \mathrm{l}$ RNA Wash Solution (with ethanol added) was added and centrifuged at12,000 $14,000 \times \mathrm{g}$ for 1 minute. $250 \mu \mathrm{l}$ RNA Wash Solution was added and centrifuged at high speed for 2 minutes. For each sample, one capped $1.5 \mathrm{ml}$ Elution Tube were removed. The 


\section{International Journal of Science and Research (IJSR) \\ ISSN (Online): 2319-7064 \\ Index Copernicus Value (2013): 6.14 | Impact Factor (2015): 6.391}

Spin Basket from the Collection Tube was transferred to the Elution Tube, and $100 \mu \mathrm{l}$ Nuclease-Free Water was added to the membrane. The Spin Basket Assemblies were placed in the centrifuge with the lids of the Elution Tubes facing out then centrifuged at $12,000-14,000 \times \mathrm{g}$ for 1 minute. The Spin Basket was removed and discarded. The Elution Tube containing the purified RNA was capped and stored at $70^{\circ} \mathrm{C}$.

\section{Determination of RNA Purity and concentration}

This method is used to estimate the purity of the RNA by using a NanoDrope Spectrometer.

\section{Partial IgVH Region Amplification and Sequencing}

The partial IgVH Region was amplified using of specific primer pair using in RT-PCR reactions which provide a simple and rapid method for preparation of a specific region of cDNA for sequencing. This part of research was done in ASCO Learning Center/Al-Harthia/Baghdad.

\section{Primers}

Lyophilized primers were dissolved in a nuclease free water to give a primary concentration of $(100 \mu \mathrm{M})$ (as stock solution). For working solution, $10 \mu \mathrm{l}$ of stock was diluted with $90 \mu \mathrm{l}$ of nuclease free water to get $(10 \mu \mathrm{M})$ as a final concentration. The sequence of these primer was explained in Table: (1).

Table 1: Primer Sequence used for GSTM1 deletion detections.

\begin{tabular}{|c|c|c|}
\hline Primer & Size & Sequence \\
\hline VH FR2 & \multirow{2}{*}{$\mathbf{2 0 0}$} & TGGRTCCGMCAGSCYYCNGG \\
\cline { 1 - 1 } JH JHE & & ACCTGAGGAGACGGTGACC \\
\hline
\end{tabular}

RT PCR (Marasca, et al., 2005),

One Step Reverse Transcription PCR and specific primers were used as the following calculation and programming:

Table 2: Mixture A component

\begin{tabular}{|c|c|}
\hline Component & Volume $(\mu \mathrm{l})$ \\
\hline qPCR Mix & 12.5 \\
\hline RT mix & 0.5 \\
\hline VH FR2 & 1 \\
\hline JH JHE & 1 \\
\hline Nuclease free water & 8 \\
\hline DNA sample & 2 \\
\hline Final volume & 25 \\
\hline
\end{tabular}

Table 3: PCR program for mixture $A$

\begin{tabular}{|c|c|c|c|c|}
\hline No & Steps & Temperature & Time & No. Of cycles \\
\hline 1 & DNA synthesis & 37 & $15 \mathrm{~min}$ & \\
\hline 2 & Initial Denaturation & $95 \mathrm{C}^{\circ}$ & $5 \mathrm{~min}$ & 1 cycle \\
\hline \multirow{3}{*}{3} & Denaturation & $94 \mathrm{C}^{\circ}$ & $30 \mathrm{sec}$ & \multirow{3}{*}{35 cycles } \\
\cline { 2 - 4 } & Annealing & $60 \mathrm{C}^{\circ}$ & $30 \mathrm{sec}$ & \\
\cline { 2 - 4 } & Extension 1 & $72 \mathrm{C}^{\circ}$ & $30 \mathrm{sec}$ & \\
\hline 4 & Final Extension & $72 \mathrm{C}^{\circ}$ & $7 \mathrm{~min}$ & 1 cycle \\
\hline 5 & Holding & $4 \mathrm{C}^{\circ}$ & - & 1 cycle \\
\hline
\end{tabular}

Agarose of Gel Electrophoresis (Sambrook et al., 1989) After DNA extraction and PCR amplification, Agarose gel electrophoresis was adopted to confirm the presence and integrity of the extracted DNA or amplification. PCR was completely dependable on the extracted DNA criteria.

\section{Preparation of agarose}

$100 \mathrm{ml}$ of $1 \mathrm{X}$ TBE was taken in a beaker. $1 \mathrm{gm}$ (for $1 \%$ ) agarose was added to the buffer. The solution was heated to boiling (using water bath) until all the gel particles were dissolved. $1 \mu \mathrm{l}$ of Ethidium Bromide $(10 \mathrm{mg} / \mathrm{ml})$ was added to the agarose. The agarose was stirred in order to get mixed and to avoid bubbles.The solution was allowed to cool down at $50-60 \mathrm{C}^{\circ}$.

\section{Casting of the horizontal agarose gel}

The agarose solution was poured into the gel tray after both the edges were sealed with cellophane tapes and the agarose was allowed to gel at room temperature for 30 minutes. The comb was carefully removed and the gel was placed in the gel tray. The tray was filled with $1 \mathrm{X}$ TBE-electrophoresis buffer until the buffer reached 3-5 mm over the surface of the gel.

\section{DNA loading}

$2 \mu 1$ of loading buffer was applied to each $5 \mu \mathrm{l}$ DNA sample, and samples were added carefully to the individual wells. PCR products were loaded directly. Electrical power was turned on at $7 \mathrm{v} / \mathrm{cm}$ for $1-2 \mathrm{~h}$. DNA moved from Cathode to plus Anode poles. The Ethidium bromide stained bands in gel were visualized using Gel imaging system.

\section{DNA Sequencing}

PCR products were performed and sent for sequencing by Macrogen Company/Korea. Data were analysed using immunoglobulins and T cell receptor sequences (IgBLAST).

\section{Results and Discussion}

\section{Antioxidant profile}

The serum level of the antioxidant glutathione (GSH) was significantly lowered, and that of the lipid peroxidation byproduct, malondialdehyde (MDA) was significantly elevated in the untreated newly diagnosed (followed up for a median of 4.5 months ( range 1-8 months)) and old treated CLL patients (range 4 months -8.5 years and median of $(21.5$ months)) compared with healthy controls (Table 4) and (Table 5).

Table 4: Antioxidant profile in control and newly diagnosed (untreated and treated) CLL patients: A follow up study.

\begin{tabular}{|c|c|c|c|}
\hline Parameters & \multirow{2}{*}{$\begin{array}{c}\text { Control } \\
(n=19)\end{array}$} & \multicolumn{3}{|c|}{$\begin{array}{c}\text { Newly diagnosed CLL Patients } \\
(n=18)\end{array}$} & $\begin{array}{c}\text { Treated } \\
(4.5 \text { months }) \\
(n=14)\end{array}$ \\
\hline $\begin{array}{c}\text { Glutathione } \\
(\mathrm{GSH})(\mu \mathrm{g} / \mathrm{ml})\end{array}$ & $26.45 \pm 3.78^{\text {(a) }}$ & $6.45 \pm 2.85^{\text {(b) }}$ & $7.52 \pm 1.78^{\text {(b) }}$ \\
\hline $\begin{array}{c}\text { Malondialdehyde } \\
\text { MDA }(\mathrm{nmol} / \mathrm{ml})\end{array}$ & $2.09 \pm 0.94^{\text {(a) }}$ & $4.09 \pm 1.08^{\text {(b) }}$ & $3.55 \pm 0.80^{\text {(c) }}$ \\
\hline
\end{tabular}

Values are expressed as mean \pm standard deviation (SD). Values with different letters within each parameter are significantly different $(\mathrm{P}<0.05)$ 


\section{International Journal of Science and Research (IJSR) \\ ISSN (Online): 2319-7064 \\ Index Copernicus Value (2013): 6.14 | Impact Factor (2015): 6.391}

Table 5: Antioxidant profile in control, untreated newly diagnosed and old treated CLL patients (for a median 21.5 months)

\begin{tabular}{|c|c|c|c|}
\hline Parameters & Control $(\mathrm{n}=19)$ & \multicolumn{2}{|c|}{ CLL Patients } \\
\cline { 3 - 4 } & $\begin{array}{c}\text { untreatednewly } \\
\text { diagnosed }\end{array}$ & $\begin{array}{c}\text { Old treated } \\
(21.5 \text { months }) \\
(\mathrm{n}=37)\end{array}$ \\
\hline $\begin{array}{c}\text { Glutathione } \\
(\mathrm{GSH})(\mu \mathrm{g} / \mathrm{ml})\end{array}$ & $26.45 \pm 3.78^{\text {(a) }}$ & $6.45 \pm 2.85^{\text {(b) }}$ & $7.52 \pm 1.78^{(\mathrm{b})}$ \\
\hline $\begin{array}{c}\text { Malondialdehyde } \\
\text { MDA (nmol/ml) }\end{array}$ & $2.09 \pm 0.94^{\text {(a) }}$ & $4.09 \pm 1.08^{(\mathrm{b})}$ & $3.24 \pm 1.78^{(\mathrm{c})}$ \\
\hline
\end{tabular}

Values are expressed as mean \pm standard deviation (SD)

Values with different letters within each parameter are significantly different $(\mathrm{P}<0.05)$

Follow-up analysis of untreated CLL patients for a median of 4.5 months of RFC therapy failed to normalize both GSH and MDA levels, suggesting the persistence of endogenous oxidative stress in the treated CLL patients on one hand, and the lack of antioxidant activity of RFC combination therapy on the other hand. To the best of our knowledge, there is no evidence in the available literature suggesting that these anti-leukemic drugs possess any antioxidant activities. Furthermore, evidence is available demonstrating that rituximab (De Rosa et al., 2015), fludarabine + cyclophosphamide (Goncalves et al., 2009) are capable of inducing ROS-induced oxidative stress in biological systems.

Therefore, the observed decreased GSH levels in CLL subjects may reflect depletion of non-enzymatic antioxidant reserve and the presence of endogenous oxidative stress. Evidence in available suggesting the presence of increased oxidative stress in CLL (Zhou et al., 2003; Collado et al., 2012; Gaman et al., 2014).

The decreased serum levels of reduced GSH in the present study agrees with that of Bakan et al., (2003) who reported a lower serum GSH levels in patients with CLL compared with controls.

Recently Jitschin et al., (2014) identified altered mitochondrial metabolism (notably, increased oxidative phosphorylation) in untreated CLL cells as the key source for the abundant ROS. Also, they demonstrated that CLL cells adapted to intrinsic oxidative stress through mechanisms involving promoting mitochondrial biogenesis (which in turn may enhance mitochondrial ROS output), suggesting that ROS adaptations to ROS, and mitochondria biogenesis appear to form a self-amplifying feedback loop in CLL cells.

On the other hand, Conklin (2004) suggested that the use of antioxidants during cancer chemotherapy, may enhance therapy by reducing the generation of oxidative stressinduced electrophilic aldehydes that can attack many cellular targets and diminish the efficacy of the treatment. Recently, Mut-Salud, et al., (2016) demonstrated that the convenience of administration of antioxidants during cancer therapy still remains a very controversial issue, because the final effect will depend on the type of cancer, the mechanism of action of the $\operatorname{drug}(\mathrm{s})$ used, and the type of antioxidant. Accordingly, they concluded that the supplementation (or restriction) of exogenous antioxidants during cancer therapy, when appropriate, could contribute to improving its efficacy.

The finding of elevated serum levels of MDA in the untreated newly diagnosed and old treated CLL patients agrees with that of Zelen et al., (2010) who reported significantly higher plasma MDA level in the CLL patients compared with controls, suggesting the presence of over production of ROSinduced oxidative stress in the untreated CLL patients. Elevated MDA level were also observed in supernatants of lymphocytes cultures of untreated CLL patients, suggesting that oxidative stress in CLL lymphocytes could be one of the potential mechanisms in the pathogenesis of abnormal apoptosis (Djurdjevic et al., 2009).

\section{Molecular Profile in CLL patients}

This part of research has been conducted on the partial IgVH region with amplified 240 bp using specific primers VH FR2 and JH JHE, after converted RNA being extracted from MNCs to cDNA in one step RT-PCR, for preparation the specific region for sequencing. Twenty subjects were randomly selected and involved in this experiment, eight newly diagnosed CLL patients (4 males and 4 females) and eight old treated CLL patients who are currently receiving treatment, (4 males and 4 females), and four healthy control ( 2 males and 2 females), which they are one from male and female. (Figure 2 ).

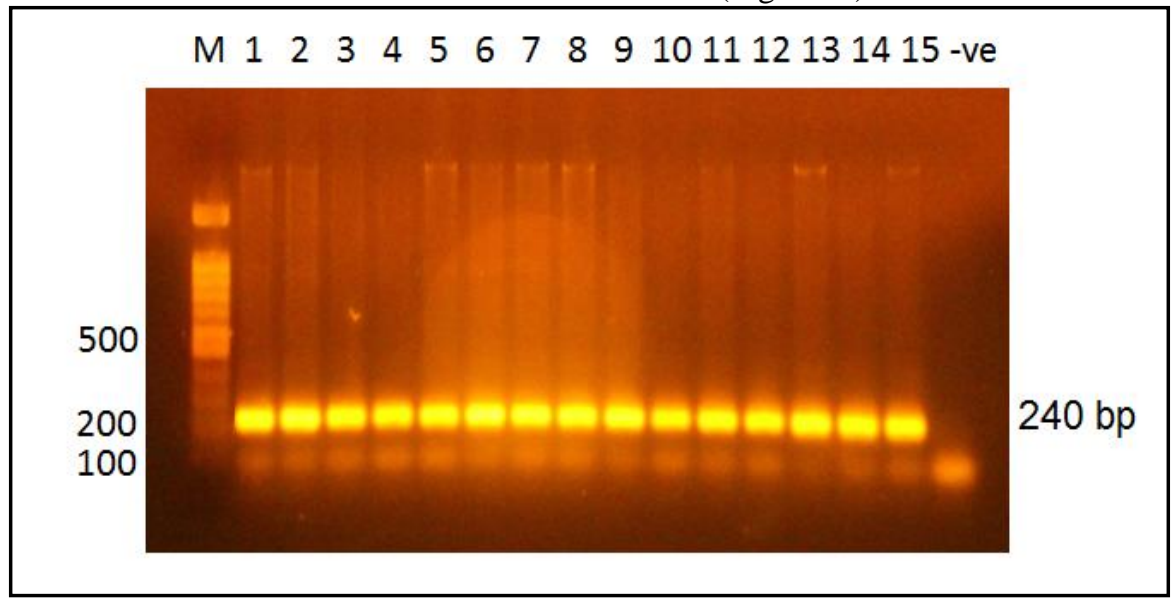

Figure 2: Gel electrophoresis for PCR amplification of IGHV gene showing band with molecular size (240bp). Electrophoresis was performed on $1.5 \%$ agarose gel and run with a 100-volt current for 2 hrs. Lane M:100 bp ladder. From 1 to 15 lane were patients and control samples. -ve: negative control.

Volume 5 Issue 6, June 2016 www.ijsr.net

Licensed Under Creative Commons Attribution CC BY 


\section{International Journal of Science and Research (IJSR) \\ ISSN (Online): 2319-7064 \\ Index Copernicus Value (2013): 6.14 | Impact Factor (2015): 6.391}

Mutations of $\mathrm{VH}$ genes of $\mathrm{Ig}$ are identified by comparing DNA sequences of genes in B cells with corresponding genes in the germline. DNA sequences of B cells differing by $2 \%$ from its germline counterpart are considered mutated (Schroeder ,et al., 1994).

Extensive molecular investigations of the B cell receptor (BCR) indicated that $60 \%-65 \%$ of CLLs carry immunoglobulin heavy-chain variable (IGHV) genes with evidence of somatic hypermutation in their variable regions, a process that occurs in the germinal center and may modify BCR affinity for antigens (Klein, et. al., 2008).

IGHV unmutated CLL cells are typically BCR signaling competent whereas IGHV mutated CLL cells respond weakly or not at all to BCR crosslinking induced by anti IgM antibodies (Tsimberidou, et al., 2009).

The mutational status of $\mathrm{IgVH}$ is also associated with specific genomic aberrations; for instance, del (17p13) or del (11q23) occurs more frequently in patients with unmutatedIgVH CLL (unmut-IgVH), whereas mutations such as $13 q-$ as sole aberrancy are generally associated with mutated IgVH (mut-IgVH) CLL (Kröber, et al., 2006).

\section{DNA Sequencing}

Evaluation of biological prognosticators was centralized in few reference laboratories, IGHV mutational status was performed as previously reported (Bomben, et al., 2009).

The immunoglobulins expressed by CLL B cells are highly restricted, suggesting they are selected for binding either self or foreign antigen of the immunoglobulin heavy-chain variable (IGHV) genes expressed in CLL (Mauerer, et al., 2005). In general, CLL patients that express unmutated Ig heavy chain (IGHV) genes have a worse prognosis than those who express mutated IGHV genes (Tsimberidou, et al., 2009)

For DNA sequencing, PCR products were performed and send to Macrogen Company/Korea. Data were analysed using immunoglobulins and $\mathrm{T}$ cell receptor sequences database provided from NCBI using IgBLAST tool. Results of sequencing reveled that healthy controls showed unmutated IGVH, figure (3).

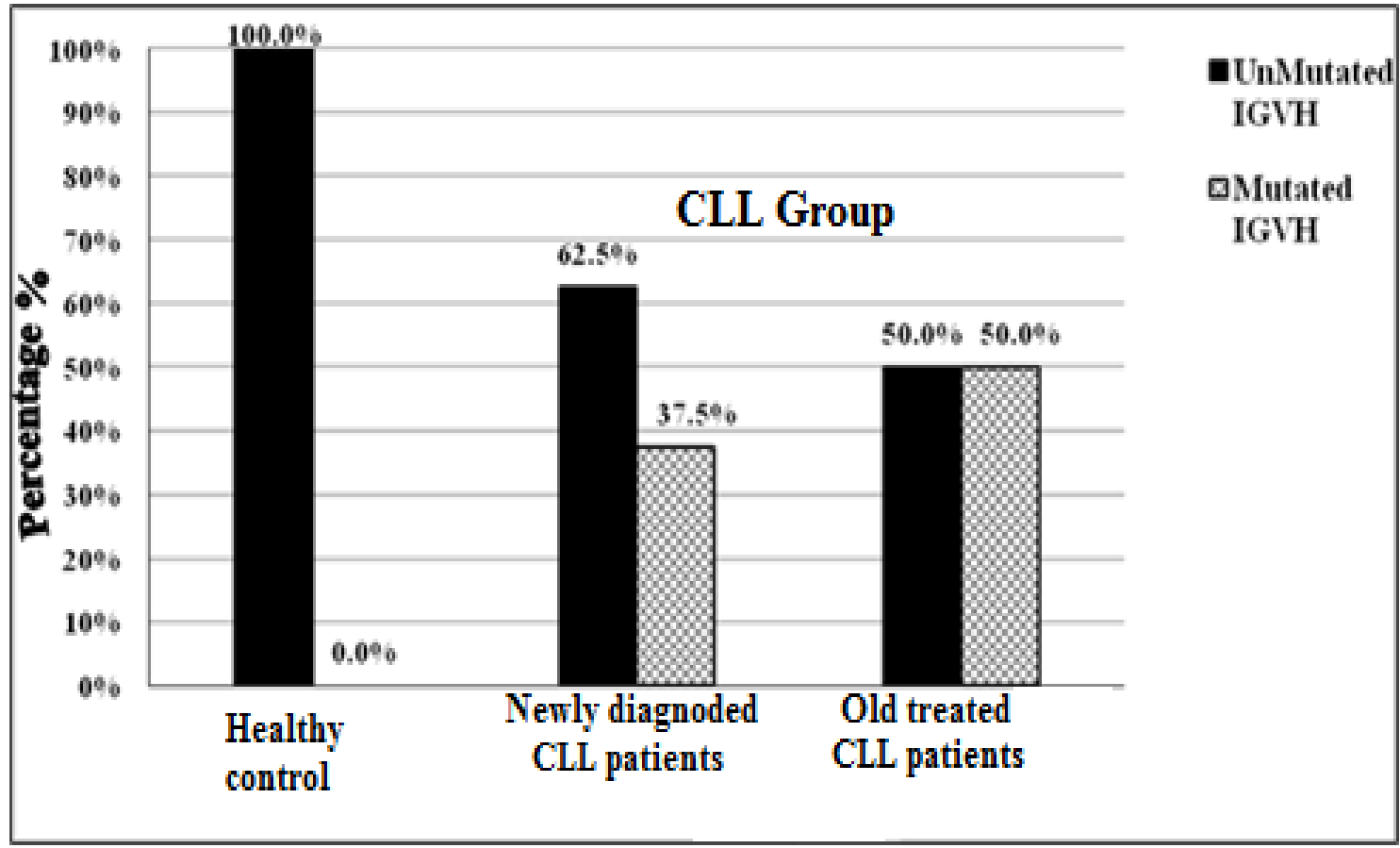

Figure 3: Mutated and unmutated IGVH in CLL patients and control.

Furthermore, figure (4) showed that healthy controls have sequencing of IGVH completely identical to immunoglobulin and T-cell receptor (IgBLAST). 


\section{International Journal of Science and Research (IJSR) \\ ISSN (Online): 2319-7064}

Index Copernicus Value (2013): 6.14 | Impact Factor (2015): 6.391

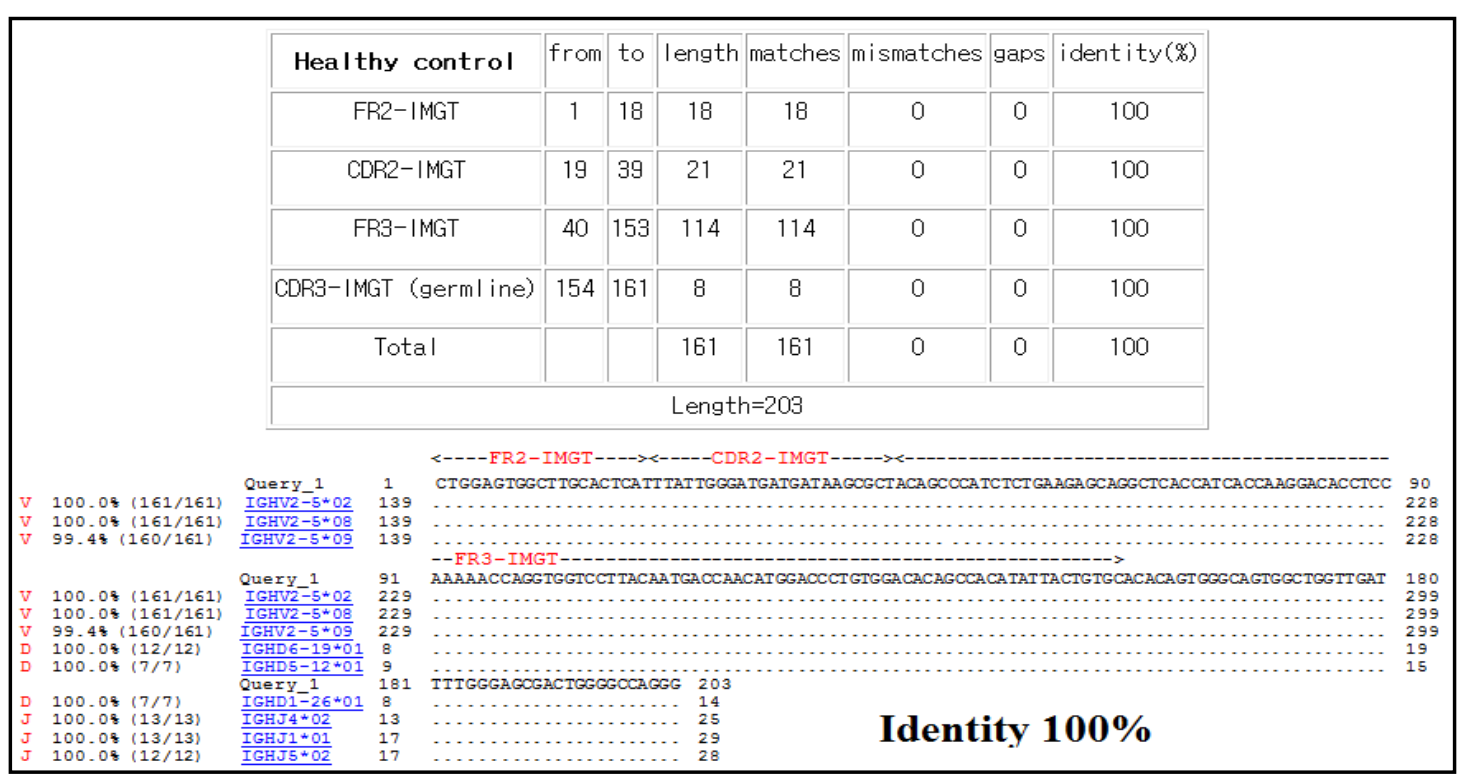

Figure 4: Sequence analysis summary of IGVH in the healthy control (IgBLAST)

Results of IGVH sequencing the newly diagnosed untreated CLL patients revealed that, $3(37.5 \%)$ out of (8) have mutated IGHV genes, at the position (FR3-IMGT) with identity (99.1\%) (Figure 4, 5). As following:

A-Mismatch one base from fragment length (207)bp at a total identity $(99.4 \%)$.
B-Mismatch one base from fragment length (203)bp at a total identity $(99.4 \%)$.

C- Mismatch one base from fragment length (191)bp at a total identity $(99.3 \%)$.

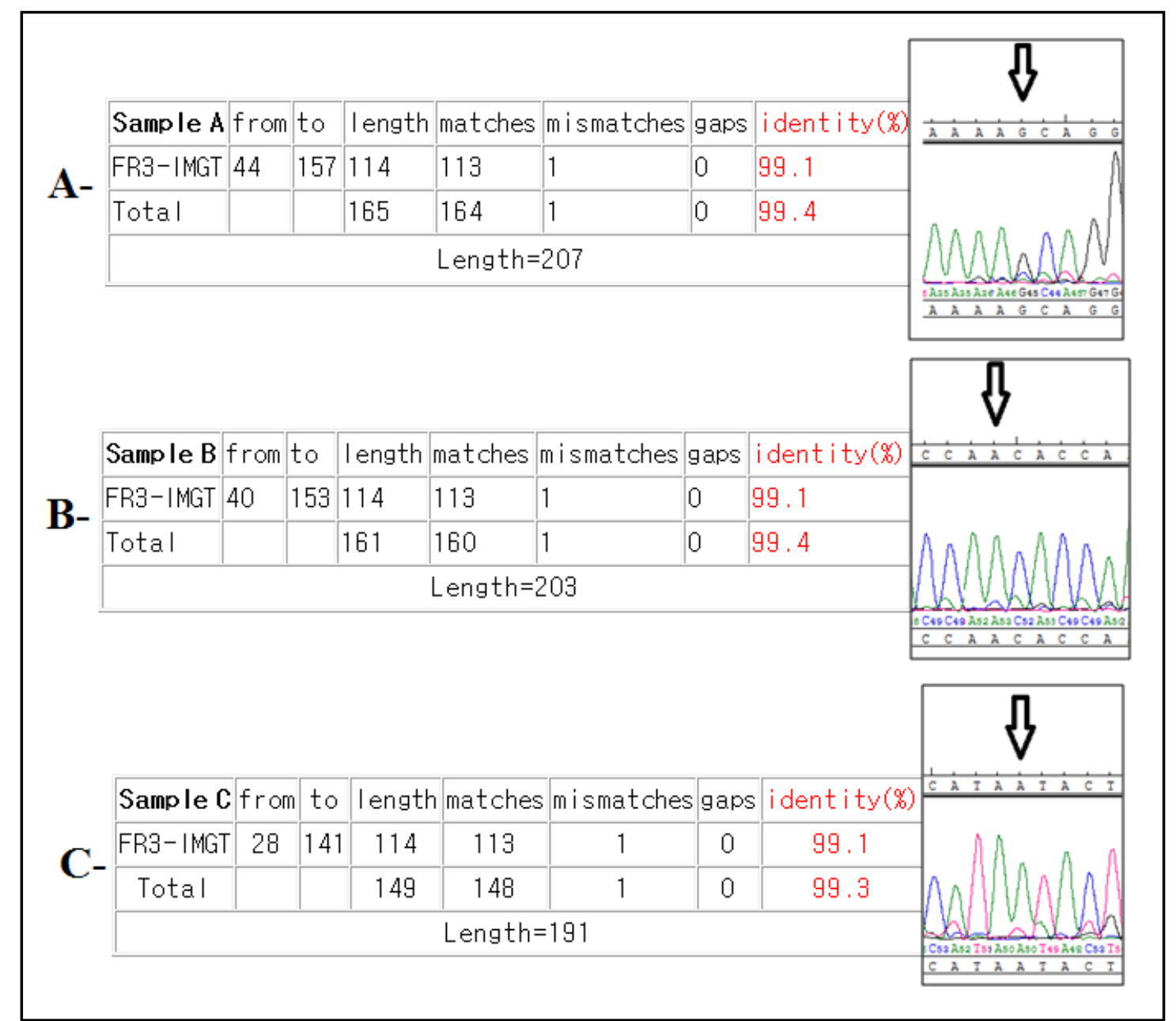

Figure 5: Sequence analysis summary of IGVH in the newly diagnosed untreated CLL patients (IgBLAST)

\section{Volume 5 Issue 6, June 2016} www.ijsr.net

Licensed Under Creative Commons Attribution CC BY 


\section{International Journal of Science and Research (IJSR) \\ ISSN (Online): 2319-7064 \\ Index Copernicus Value (2013): 6.14 | Impact Factor (2015): 6.391}

DNA sequence in the treated CLL patients revealed that, four of them $(50 \%)$ have mutated IGHV genes, at the position (FR3-IMGT) with identity $(99.1 \%)$ ( Figure 6). As following:

A-Mismatch one base from fragment length (185)bp at a total identity $(99.4 \%)$.
B-Mismatch one base from fragment length (198)bp at a total identity $(99.4 \%)$.

C- Mismatch one base from fragment length (180)bp at a total identity $(99.4 \%)$.

D- Mismatch one base from fragment length (186)bp at a total identity $(99.3 \%)$.

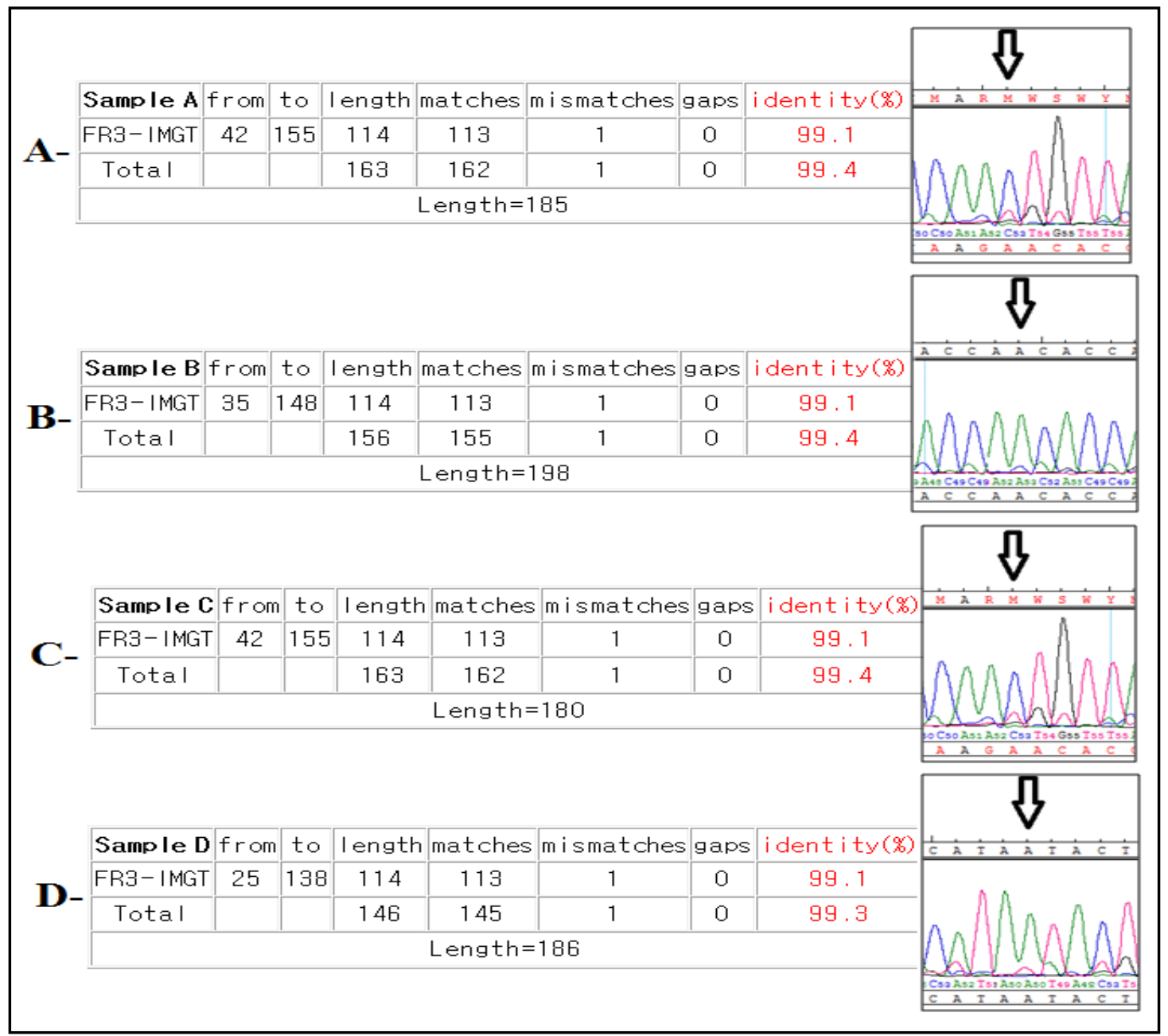

Figure 6: Sequence analysis summary of IGVH in the treated CLL patients (IgBLAST)

CLL could be divided into two prognostic subtypes based on the degree of mutation of the immunoglobulin heavy-chain variable region $(\mathrm{IgVH})$ genes (Hamblin, et al., 1999).

\section{Molecular analysis of genetic using RT-PCR}

Because these studies have focused on different prognostic factors, it is not surprising that they have identified independent sets of potential biomarkers. Novel biologic and genetic markers are providing tools to aid in the better prediction of responses, disease progression, and survival in patients with CLL. Unmut-IgVH is clearly an independent predictor of outcome in CLL patients. The correlation between unmut-IgVH and an increased risk for clonal evolution suggests that the presence of unmut- $\mathrm{VH}$ is required to induce karyotypic instability (Tobin, et al., 2003). Unmut-IgVH does not appear to independently predict for chemoresistance, but patients with unmut-IgVH CLL are reported to have shorter remissions, the prognosis of unmut-IgVH patients remains poor, even after high dose chemotherapy. (Lin, et al., 2007).

\section{Conclusions}

The present study reached the following conclusions:

The reduction in the serum levels of glutathione, along with the elevation in serum MDA levels of CLL patients suggest the presence of an increased endogenous oxidative stress in CLL patients. The inability of (RFC) chemotherapy to normalize both serum GSH and MDA levels in treated CLL patients is suggestive of a lack of an antioxidant activity of these drugs, and the persistence of endogenous oxidative stress in treated CLL patients. Sequence analysis of IGVH gene revealed that 3 out of the 8 tested newly diagnosed CLL patients and 4 out 8 tested treated CLL patients had mutated IGVH, while none of the 4 tested healthy controls showed mutated IGVH.

\section{References}

[1] Bakan N, Taysis S, Yailmaz O, et al. Glutathione peroxidase, glutathione reductase, $\mathrm{CU}-\mathrm{Zn}$ superoxide

Volume 5 Issue 6, June 2016 www.ijsr.net

Licensed Under Creative Commons Attribution CC BY 


\section{International Journal of Science and Research (IJSR) \\ ISSN (Online): 2319-7064 \\ Index Copernicus Value (2013): 6.14 | Impact Factor (2015): 6.391}

dismutase activities, glutathione, nitric oxide, and MDA concentrations in serum of patients with CLL. Clin chim Acta. 2003: 338 143-9.

[2] Bomben R, et al., : Molecular and clinical features of chronic lymphocytic leukaemia with stereotyped B cell receptors: results from an Italian multicentre study. $\mathrm{Br}$ J Haematol 2009, 144(4):492-506.

[3] Calin GA, Ferracin M, Cimmino A, et al. : A microRNA signature associated with prognosis and progression in chronic lymphocytic leukemia. N Engl J Med 2005, 353:1793-1801.

[4] Catovsky D, Montserrat E. Chronic lymphocytic leukaemia and other B-cell disorders. In: Hoffbrand AV,Catovsky D, et al (ed). Postgraduate Haematology. $6^{\text {th }}$ edition.UK: Blackwell Publishing; 2011.p:530-556.

[5] Collado, R. Oliver, I. Tormos C. et al., "Early ROSmediated DNA damage and oxidative stress biomarkers in Monoclonal B Lymphocytosis," Cancer Letters, vol. 317, no. 2, pp. 144-149, 2012. [PubMed: 22115963].

[6] Conklin KA. Chemotherapy-associated oxidative stress: impact on chemotherapeutic effectiveness. Integr Cancer Ther. 2004; 3: 294-300.

[7] Damle RN, Wasil T, Fais F, et al. Ig V gene mutation status and CD38 expression as novel prognostic indicators in chronic lymphocytic leukemia. Blood. 1999; 94:1840-1847. [PubMed: 10477712]. 16.

[8] De Rosa A, Zappavigna S, Villa MR, et al. Prognostic role of translocator protein and oxidative stress markers in CLL patients treated with bendamustine plus rituximab. Oncology Lett. 2015: 9: 1327-32.

[9] DJurdjevic P, Zelen I, Ristic P, et al. Oxidative stress accelerates spontaneous apoptosis of B-CLL lymphocyte. J BOUN. 2009: 14: 281-7. [PMID: 19650179].

[10] Dooley, H., and Flajnik, M. F. Antibody repertoire development in cartilaginous fish. Dev. Comp. Immunol. (2006). 30, 43-56.

[11] Gaman AM, Buga AM, et al. the role of oxidative stress and the effects of antioxidants on the incidence of infectious complications of CLL. Oxidative Med. Cell. Longevity 2014: Article ID 158135:1-6.

[12] Goncalves T, Benvegnu DM, Bonfanti G, et al. Oxidative stress and delta-ALA-D activity in different conditioning regimens in allogeneic bone marrow transplantation patients. Clin Biochem. 2009: 42: 60210. [PMID: 19109938].

[13] Hallek M, Cheson BD, et al. Guidelines for the diagnosis and treatment of chronic lymphocytic leukemia: a report from the International Workshop on Chronic Lymphocytic Leukemia updating the National Cancer Institute-Working Group 1996 guidelines,Blood. June 15, 2008; vol. 111 (no12): page 5446-5456.

[14] Halliwell, B. Biochemistry of oxidative stress .J. Biochemical Society Transfections, (2007). 35: 11471150.

[15] Hamblin T, Davis Z, Gardiner A, Oscier Det al. Unmutated $\operatorname{Ig} \mathrm{V}(\mathrm{H})$ genes are associated with a more aggressive form of chronic lymphocytic leukemia. Blood. 1999; 94:1848-1854. [PubMed: 10477713].
[16] Hernández JA, Land KJ, McKenna RW. Leukemias, myeloma, and other lymphoreticular neoplasms, Cancer.1995; 75:381.

[17] Humphries C. Adoptive cell therapy: Honing that killer instinct. Nature. 2013; 504:S13-15.

[18] Jitschin R, Hofmann AD, Bruns H, et al. : Mitochondrial metabolism contributes to oxidative stress and reveals therapeutic targets in chronic lymphocytic leukemia. Blood 2014, 123:2663-2672.

[19] Kipps TJ. Chronic lymphocytic leukemia. Curr Opin Hematol. 2000; 7:223-34. [PubMed: 10882178].

[20] Klein U, Dalla-Favera R. Germinal centres: role in Bcell physiology and malignancy, Nat Rev Immunol. 2008;8(1):22-33.

[21] Kröber A, Bloehdorn J, Hafner S, et al.: Additional genetic high-risk features such as $11 \mathrm{q}$ deletion, $17 \mathrm{p}$ deletion, and V3-21 usage characterize discordance of ZAP-70 and VH mutation status in chronic lymphocytic leukemia, J ClinOncol . 2006; 24 (6): 969.

[22] Küppers R, Rajewsky K. Developmental and functional biology of B lymphocytes. In: Mauch PM, Armitage JO, Coiffier B, Dalla- Favera R, Harris NL, eds. NonHodgkin's Lymphomas. Philadelphia, PA: Lippincott Williams \& Wilkins; 2004:771-786.

[23] Kyrtsonis, E. Koulieris, V. Bartzis et al., "Monoclonal immunoglobulin," in Multiple Myeloma-A Quick Reflection on the Fast Progress, R. Hajek, Ed., 2013.

[24] Lin KI, Tam CS, Abruzzo LV, et al. IgVH mutational status does not affect complete remission rate but is associated with reduced remission duration in CLL patients treated with fludarabine, cyclophosphamide and rituximab (FCR)- based therapy [abstract]. Blood. 2007;110:232a. Abstract 753.

[25] Mauerer K, Zahrieh D, Gorgun G, et al. Immunoglobulin gene segment usage, location and immunogenicity in mutated and unmutated chronic lymphocytic leukaemia. Br J Haematol. (2005), 129: 499-510.

[26] Moreton P, Kennedy B, et al. Eradication of Minimal Residual Disease in B-Cell Chronic Lymphocytic Leukemia After Alemtuzumab Therapy Is Associated With Prolonged Survival, Journal of clinical oncology.2005 May 1;23(13):2971-9.

[27] Mut-Salud N, Alvarez PJ, Garrido JM, et al. Antioxidant intake and antitumor therapy: Toward Nutritional recommendations for optimal results. Oxid Med. Cell. Longevity 2016: volume 2016: Article ID 6719534: 1-19.

[28] Oltra, F. Carbonell, C. Tormos, A. Iradi, and G. T. Saez, - "Antioxidant enzyme activities and the production of MDA and 8-oxo-dG in chronic lymphocytic leukemia," Free Radical Biology \& Medicine, vol. 30, no. 11, pp. 1286-1292, 2001.

[29] Pettitt AR, Dreger P, et al. Chronic lymphocytic leukaemia, Lymphoma Association .Produced 03.02.2012.

[30] Schroeder HW Jr, Dighiero G. The pathogenesis of chronic lymphocytic leukemia: analysis of the antibody repertoire. Immunol Today. 1994;15:288-294.

[31] Tobin G, Thunberg U, Johnson A, et al. Chronic lymphocytic leukemias utilizing the VH3-21 gene display highly restricted Vlambda2-14 gene use and homologous CDR3s: implicating recognition of a 


\section{International Journal of Science and Research (IJSR) \\ ISSN (Online): 2319-7064}

Index Copernicus Value (2013): 6.14 | Impact Factor (2015): 6.391

common antigen epitope. Blood. 2003; 101:49524957. [PubMed: 12586612].

[32] AM Tsimberidou, Wen S, McLaughlin P, et al. Other malignancies in chronic lymphocytic leukemia/small lymphocytic lymphoma. J Clin Oncol. 2009; 27:904910. [PubMed: 19114699].

[33] Wu G, Fang YZ, Yang S, Lupton JR, Turner ND. (2004). Glutathione Metabolism and Its Implications for Health. J Nutr; 134:489-92.

[34] www.partec.com/applications.html accessed at July,10,2013.

[35] Zelen I, Djurdjevic P, Popovic S, et al. Antioxidant enzymes activities and plasma levels of oxidative stress markers in B-CLL. J BOUN. 2010: 15:330-6. [PMID: 20658731].

[36] Zhou Y, Hileman EO, Plunkett W, et al. Free radical stress in chronic lymphocytic leukemia cells and its role in cellular sensitivity to ROS-generating anticancer agents. Blood. 2003;101(10):4098-4104.

Volume 5 Issue 6, June 2016 www.ijsr.net 